\title{
Ultrastructural aspects of mammalian fertilization: new discoveries and inspirations from the work of Daniel Szöllösi
}

\author{
Peter Sutovsky, Gerald Schatten*
}

\author{
Departments of Obstetrics and Gynecology, and Cell and Developmental Biology, \\ Oregon Health Sciences University, and the Oregon Regional Primate Research Center, \\ 505 N.W. 185th Avenue, Beaverton, OR 97006, USA
}

(Received 1 October 1998; accepted 14 October 1998)

\begin{abstract}
Our current level of knowledge on mammalian fertilization would not be attained without the contribution of ultrastructural studies. The late Daniel Szöllösi, to whose memory this review is dedicated, was one of the most enthusiastic explorers of this fascinating field. In his landmark electron microscopic studies, he revealed the importance of nuclear envelope breakdown for oocyte maturation and its reconstitution after fertilization, and predicted the era of cloning by publishing articles on the remodeling of a somatic cell, thymocyte nucleus fused with an oocyte. His challenge of Boveri's hypothesis on the paternal inheritance of centrosomes spurred further research on this subject that ultimately led to the definition of biparentally contributed mammalian zygotic centrosomes, for which the only exception is found in rodents. Very early, Szöllösi and his colleagues devoted their interest to the studies of the fate of sperm accessory structures after fertilization, an area that has yet to be explored at the molecular level, but which may have profound implications for the swiftly advancing field of assisted human and animal reproduction. These studies contributed a great deal to our current understanding of mammalian fertilization and still serve as an inspiration for present studies on involved mechanisms. (C) Inra/Elsevier, Paris.
\end{abstract}

\section{mammals / fertilization / oocyte maturation / nuclear transfer / ultrastructure}

Résumé - Aspects ultrastucturaux de la fécondation chez les Mammifères : nouvelles découvertes suscitées par l'œuvre de Daniel Szöllösi. Les connaissances actuelles sur la fécondation chez les Mammifères n'auraient pas été obtenues sans d'études ultrastructurales. Le regretté Daniel Szöllösi, à la mémoire duquel cette revue est dédiée, était un des explorateurs les plus enthousiastes dans ce domaine. Dans ses études marquantes de microscopie électronique, il a révélé l'importance de la rupture de l'enveloppe nucléaire pour la maturation de l'ovocyte et sa reconstitution après fécondation ; il a annoncé l'ère du clonage en publiant des articles sur le remodelage du noyau d'une cellule somatique, le thymocyte, fusionné avec un ovocyte. En défiant l'hypothèse classique du

\footnotetext{
* Correspondence and reprints

E-mail: schatten@ohsu.edu
} 
Boveri de l'héritage paternel du centrosome, il inspira de nouvelles recherches sur le sujet qui conduisirent à la mise en évidence de l'origine biparentale du centrosome zygotique, à l'exception des rongeurs. Très tôt, Szöllösi et ses collègues se sont intéressés au devenir de structures accessoires des spermatozoïdes après la fécondation chez les mammifères et sont toujours une source d'inspiration pour des recherches sur les mécanismes impliqués. (C Inra/Elsevier, Paris.

mammifères / fécondation / maturation ovocytaire / transfert nucléaire / ultrastructure

\section{INTRODUCTION}

In contrast to the widespread general perception, the paternal contributions to the functional zygote are not limited to introducing one half of the future embryonic genome into oocyte cytoplasm. Several other sperm structures, including sperm mitochondria, perinuclear theca (PT) and a reduced form of the sperm centrosome, are brought into oocyte cytoplasm where they participate in the organization of zygotic development. Since the sperm cytoplasm is almost completely eliminated during spermiation and only certain types of cellular organelles are retained during spermatogenesis, the mammalian zygote relies on the interactions between these sperm-borne elements and rich oocyte pools of organelles and molecules for its developmental success. The extensive body of work published by the late Daniel Szöllösi was prophetical in that it pointed out to many structural events of mammalian fertilization long before the molecular tools for their characterization became available. In this review, the new research aimed at reevaluating the importance of these early developmental events for natural and assisted fertilization and early embryogenesis, is reviewed together with the original works that inspired it. The recent revival of the techniques of nuclear transfer of somatic and germ cells elicited important questions and concerns regarding the introduction of heterogeneous cellular organelles into such in vitro reconstituted zygotes and is likely to bring the focus back on research of paternally inherited zygotic structures. It is our great plea- sure and honor to dedicate this paper to the bright memory of Dr Daniel Szöllösi, a truly exceptional man, whose body of work will serve as an inspiration for many future generations of developmental and reproductive biologists.

\section{CENTROSOME INHERITANCE AT FERTILIZATION: MATERNAL MODE IN RODENTS VERSUS BIPARENTAL CONTRIBUTIONS TO THE ZYGO'TIC CENTROSOME IN OTHER MAMMALS}

Boveri's [5] hypothesis on the paternal inheritance of centrosome during fertilization was given substantial support by Szöllösi's discovery of the paucity of centrioles in unfertilized mammalian oocytes [86]. Using pig zygotes, Szöllösi and Hunter [84] were among the first investigators to point out that the fertilizing mammalian spermatozoon introduces the centriole into oocyte cytoplasm. Although Szöllösi [83] interpreted these findings as a loss of the centriole during fertilization, it later became evident that during gametogenesis, sperm and oocyte organelles are reduced in a complementary fashion to prevent the redundancy of cellular organelles participating in early embryonic development. Although oocyte cytoplasm is retained and even amplified during oogenesis, its microtubule organizing center, the centrosome composed of two cylindrical centrioles and pericentriolar material, disappears completely. Consequently, the spindle poles are acentriolar 
during first and second oocyte meiosis [87]. Of the two centrioles seen in mammalian spermatogenic cells before spermiation, the distal centriole disappears after giving rise to the sperm axoneme, although the proximal centriole is retained and remains intact in the capitulum of the sperm tail connecting piece $[16,56]$. After gamete fusion, this proximal centriole is released from oocyte cytoplasm [43, 76, 77] and becomes surrounded by the oocyte produced, $\gamma$-tubulinrich pericentriolar material $[18,30,73,76]$, in which the ability to nucleate microtubules resides [21]. Subsequently, the radial array of microtubules, sperm aster, is organized around the sperm centriole from tubulins and centrosomal proteins. The centriole inside this zygotic centrosome later duplicates and both the mother and daughter centrioles give rise to one spindle pole each. Thus, the sperm-borne centriole is necessary for the organization of microtubules during fertilization and first embryonic cleavage, which also requires centrosomal proteins from the oocyte cytoplasm. Such biparental mode of centrosomal inheritance was described in the rabbit [59], humans $[63,64,69]$, rhesus $[24,76,104]$, bovine $[43,77]$, sheep [11,37], pig [32] and common marsupial Monodelphis domestica [6]. An alternative mode of centrosomal inheritance was discovered in the mouse, which relies exclusively on the maternal microtubule-organizing elements $[66,67]$. Both centrioles are degraded during spermiogenesis in the mouse [41] and rat [103], and multiple acentriolar microtubule organizing centers, entirely derived from oocyte cytoplasm, control the pronuclear apposition and mitotic spindle formation in the mouse [66, 67] and hamster [25].

Even though the sperm centriole is necessary for syngamy and first mitosis in mammals with paternally contributed centrosomes, the ability of their oocytes to organize microtubules independently has been retained during evolution: parthenogenetically activated non-rodent mammalian oocytes organize mitotic spindles with acen- triolar pores $[32,43,58,85]$. Szöllösi and Ozil [85] demonstrated the de novo formation of centrioles in the blastocysts obtained by parthenogenetic activation of rabbit oocytes. Although parthenogenetic activation may generate blastocysts, this developmental mode is not full term in mammals.

The sperm axoneme that houses the centriole is a complex structure composed of a $9+1$ arrangement of microtubule doublets, paralleled by nine outer dense fibers (ODF) in the axonemal principal piece and mid piece. In the connecting piece, which serves for the attachment of the axoneme to the basal plate of the sperm nucleus, the ODF are transformed into compositionally similar, yet morphologically distinct striated columns, caging the capitulum-embedded proximal centriole. Both the connecting piece and mid piece are wrapped in a helix of sperm mitochondria (for reviews, see [16, 56]). During fertilization, the uppermost mitochondria are removed from the mitochondrial sheath, thus unmasking the connecting piece columns that are subsequently excised from the sperm nucleus, and eventually dismantled $[76,77]$. This event leads to the release of the sperm centriole in the zygotic cytoplasm and to its transformation into an active zygotic centrosome $[37,76$, 77]. Such disassembly of the connecting piece during fertilization appears to be facilitated by the removal of disulfide bond cross-linking from sperm proteins by oocyteproduced tripeptide glutathione [75]. Phosphorylation/dephosphorylation events [38, 59] and calcium binding by centrosomal proteins such as centrin $[17,61]$ may also contribute to this process.

\section{DENUDATION AND REMODELING OF THE SPERM NUCLEUS INTO A MALE PRONUCLEUS}

The primary binding event between the spermatozoon and an egg involves a disintegrin-type receptor, fertilin, on the sperm 

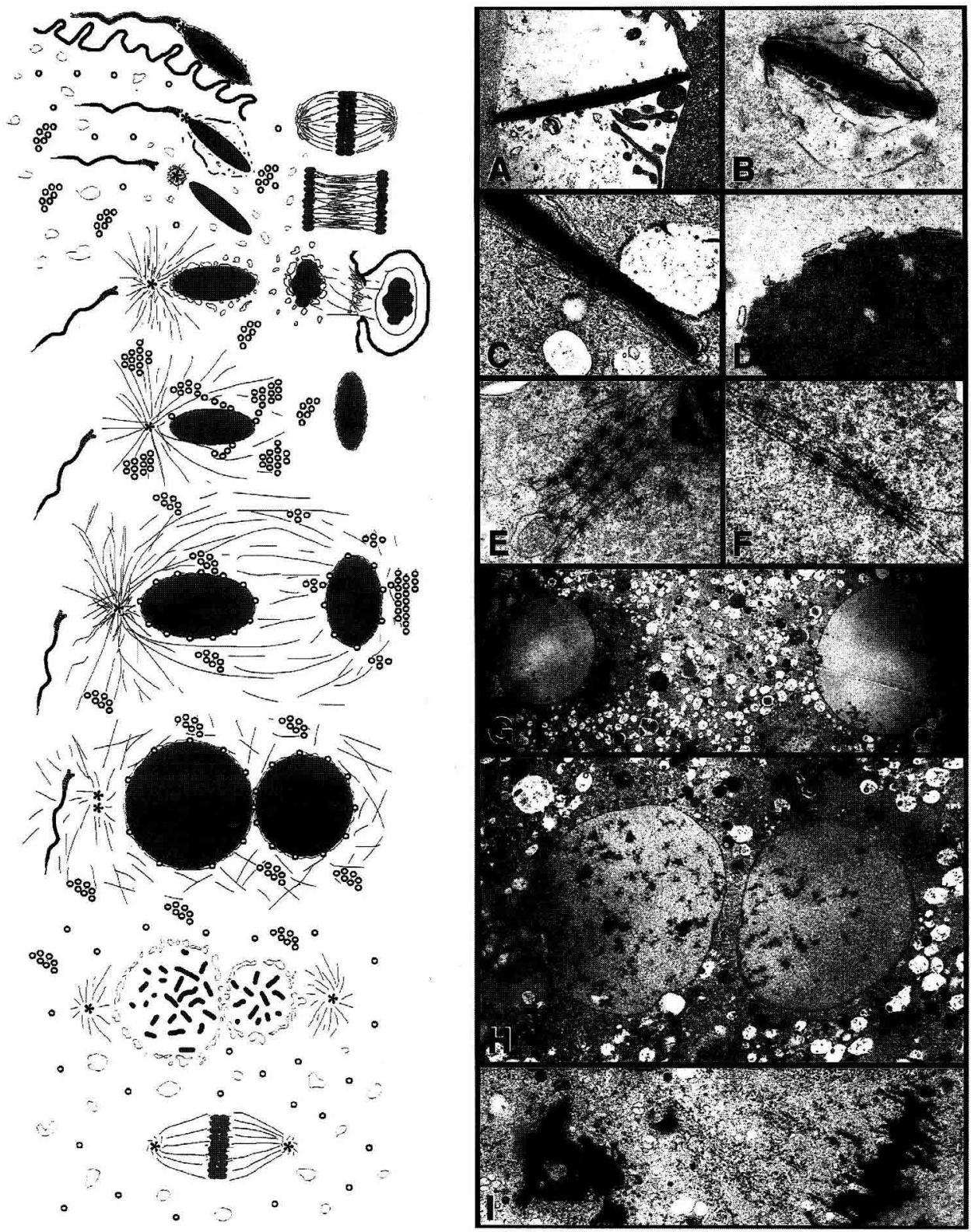

Figure 1. Early structural events of mammalian fertilization. The fertilizing spermatozoon binds to and fuses with the oolemma (A) and is deprived of its perinuclear theca and nuclear envelope during incorporation into oocyte cytoplasm (B). Following sperm incorporation, membrane vesicles gather around the sperm chromatin and fuse on its surface into a continuous nuclear envelope, at this stage lacking nuclear pore complexes $(\mathbf{C})$. Likewise, the maternal chromatin becomes separated from the cytoplasm by a nuclear envelope formed by the fusion of membrane vesicles on the surface of decondensing chromatin (D). Concomitant with the formation of the pronuclear nuclear envelopes (NEs), the sperm-borne centriole (asterisks in the drawing) is released into the oocyte cytoplasm and enu- 
plasma membrane and an integrin membrane receptor on the oolemma $[2,7,15]$. Other molecules are likely to participate in sperm egg fusion and provide either the support for, or an alternative to the integrin-fertilin-mediated gamete fusion. The sperm plasma membrane appears to intermingle with the oolemma during sperm-oocyte fusion $[39,70]$. In addition, oocyte microvilli bind to perinuclear theca (PT; $[10,48-50]$ ) a cytoskeletal coat intercalated between the sperm's plasma membrane and nuclear envelope [78]. Subsequently, the spermatozoon is dragged into and engulfed by the oocyte cytoplasm and PT is removed and dissolved in it [78]. Binding of the oocyte microvilli to PT may involve specific receptors on both sides, making this interaction a candidate for a gamete fusion event synergistic with the integrin-fertilin binding. Bull sperm with an intact PT, injected into oocyte cytoplasm, does not develop into male PN [78], suggesting that the removal of PT is a vital step in the remodeling of the sperm nucleus into a male PN. Earlier studies demonstrated the dispersion of PT in the cytoplasm of rodent oocytes $[74,83,91$, 95-97]. Evidence is growing that PT harbors the oocyte-activating oscillogenic factors $[4,53]$ that are released into oocyte cytoplasm when PT is incorporated and dissolved [35, Sutovsky et al., unpublished report]. Transcriptional factor Stat 4 has been found in murine PT [23], but the significance of this association to fertilization and early development is not known.

The intrinsic nuclear envelope (NE) of sperm disappears shortly after the removal of PT and sperm entry into oocyte cyto- plasm $[81,98]$, suggesting that sperm $\mathrm{NE}$ or any other NE introduced into metaphase II (MII) oocytes is not compatible with high maturation promoting factor (MPF) activity in the oocytes finishing second meiosis. In line with this suggestion, Szöllösi et al. [93] showed NE breakdown in the red blood cells injected into mouse oocytes within 25-45 min after activation, whereas the nuclei introduced into mouse oocytes $1-7 \mathrm{~h}$ after activation retained their intrinsic NE. Following the removal of the sperm NE, the sperm nucleus is remodeled into a male pronucleus by the action of oocyte cytoplasm $[54,75]$. The disulfide bonds in the sperm deoxyribonucleic acid (DNA)-packing proteins protamines are reduced by the action of the oocyte-generated reducing tripeptide glutathione (GSH), then removed and replaced by the oocyte-derived histones $[14,36]$. The nuclear envelope is reconstructed around the decondensing sperm nucleus from the oocyte-derived membrane vesicles $[60,75,81,98]$. This step in fertilization marks the formation of nuclear and cytoplasmic compartments in the fertilized oocyte and raises the question of when and how do these two compartments communicate and exchange the molecules necessary for normal pronuclear and embryonic development. The main channel for the nucleocytoplasmic transport in the animal cells is the nuclear pore complex (NPC; reviewed by Panté and Aebi [51]), an assembly of the O-glycosylated proteins from the nucleoporin family. The reconstitution of the NE and the assembly of NPCs in Xenopus egg extracts was very instrumental in dissecting the pathways leading to the assembly

cleates the sperm aster microtubules using the oocyte-produced tubulin molecules. Annulate lamellae $(\mathbf{E})$, the cytoplasmic stacks of nuclear pore complexes are formed in the activated oocytes and eventually recruited to the pronuclear region. Insertion of nuclear pores (0ooo) into the nuclear envelopes of the male and female pronuclei (F) provides a channel for nucleocytoplasmic transport and promotes the development of the male and female pronuclei $(\mathbf{G})$. The full size pronuclei eventually become apposed $(\mathbf{H})$ by the action of sperm aster microtubules. After reaching the apposition and completing DNA replication, the chromatin in both pronuclei recondenses, the nuclear envelopes disappear and the zygote enters first mitosis (I). The diagram was created using Adobe Illustrator 5.0 and Adobe Photoshop 4.0 software. 


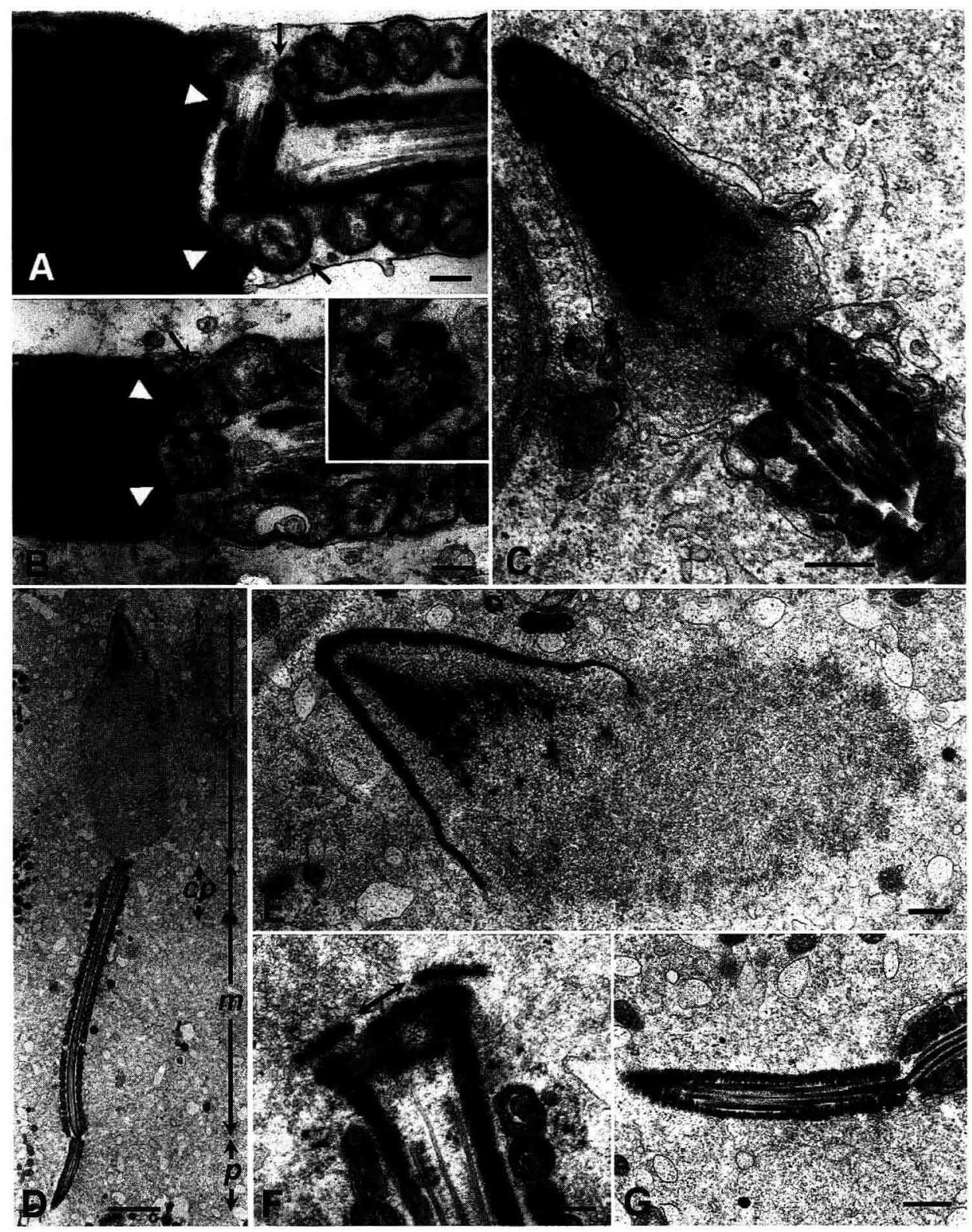

Figure 2. Early stages of sperm disassembly following intracytoplasmic sperm injection (ICSI) into rhesus monkey oocytes. Sperm centriole (asterisks and insert) in both an intact spermatozoon (A) and in the spermatozoon injected into oocyte cytoplasm $(\mathbf{B})$ is attached to the striated column of the connecting piece and wrapped in the intact mitochondrial sheath (arrows) attached to the basal plate (white arrowheads) of implantation fossa (insert: detail of centriole). Early after injection (C), the sperm plasma membrane disappears, the new nuclear envelope forms, and the decondensation of sperm chromatin begins from the base of the sperm head. The residual perinuclear theca $(\mathbf{D}, \mathbf{E})$ of the sperm head shelters the region of condensed chromatin in the acrosomal, or perforatorium region of 
of functional NE $[40,42,44,55,60,105]$. Little is known, however, about the significance and timing of this process during mammalian fertilization. Our recent studies [81] in bovine suggest that NPCs are inserted into pronuclear $\mathrm{NE}$ at the initial stage of pronuclear development and provide a vital link between the cytoplasm and the pronuclei. Cytoplasmic stacks of NPCs, called annulate lamellae (AL), are assembled in oocytes activated by fertilizing spermatozoon or by parthenogenetic stimulus [81]. AL, observed in the zygotes of most mammalian species studied up to now [76, $84,92,99]$, may be involved in the turnover of NPCs throughout pronuclear development [81]. This NPC turnover is probably directed by the zygotic centrosome and sperm aster microtubules that are associated with $\mathrm{AL}[81,91]$. Disruption of sperm aster microtubules with nocodazole prevents the assembly of NPCs at the pronuclear envelopes, blocks pronuclear development and apposition [81] and induces the blebbing of the outer leaf of pronuclear NE. Szöllösi and Szöllösi [86] suggested that nuclear blebbing, an evagination of the $\mathrm{NE}$ containing granular material that was first described in mouse zygotes, is an alternative pathway of nucleo-cytoplasmic transport in mammalian zygotes, yet this hypothesis remains to be confirmed.

\section{ELIMINATION OF SPERM MITOCHONDRIA AND SPERM TAIL AFTER FERTILIZATION}

Considering that the fertilizing mammalian spermatozoon introduces almost 100 functional mitochondria into the cytoplasm of fertilized oocytes, the strictly maternal mode of mitochondrial DNA (mtDNA) inheritance in mammals [27] is one of the most tantalizing paradoxes of developmental biology. Early observations suggesting that the sperm mitochondria disperse across oocyte cytoplasm before first embryonic cleavage [22] did little to explain such a disproportion. Later, the 'dilution' of paternal mitochondrial genome was taken into account [3]. Szöllösi [82] suggested for the first time that sperm mitochondria are targeted for destruction in oocyte cytoplasm. This view was later supported by further morphological $[12,26,68,72,77]$ and genetic $[27,31]$ studies. We conducted a study of bovine oocytes fertilized with a bull sperm that was preincubated with a vital, fixable, mitochondrion-specific probe MitoTracker Green FM (Molecular Probes Inc., Eugene, OR). In these studies, the sperm mitochondrial sheath remained compact throughout pronuclear development and traveled to one of the blastomeres during first and second mitosis. The step-wise destruction of the mitochondrial sheath appeared to take place during mitotic division, suggesting a dependence on the embryonic cell cycle [77]. Accordingly, the zygotes that became arrested in the pronuclear stage contained an intact mitochondrial sheath event after the end of the culture period, during which other zygotes reached four-cell stages and were deprived of sperm mitochondria. Almost identical results were later obtained by Cummins et al. [12], who injected the MitoTracker-tagged mouse sperm tails into cytoplasm of mature mouse oocytes. Allen [1] suggested that sperm

the sperm head $[a c$ : acrosomal region and subacrosomal perinuclear theca; $n$ : nucleus; $c p$ : connecting piece of the sperm tail; $m$ : sperm tail midpiece with mitochondrial sheath; $p$ : principal piece of the sperm tail with fibrous sheath]. The mitochondria are removed from the connecting piece with the proximal centriole (asterisk), and the basal plate (double-headed arrow) splits apart (F). The fibrous sheath is still intact at this stage of sperm disassembly (G). Scale bars represent $2 \mu \mathrm{m}$ in D, $500 \mathrm{~nm}$ in C, E and G, and $200 \mathrm{~nm}$ in A, B and F. Reprinted with publisher's permission from P. Sutovsky et al., Hum. Reprod. 11 (1996) 1703-1712. 
mitochondria may suffer extensive oxidative stress and damage during the passage through the female reproductive tract, and as such are eliminated by a mechanism that recognizes damaged mitochondria of any origin present in oocyte cytoplasm rather than by a mechanism specifically targeting paternal mitochondria. This theory, however, falls short of explaining why the mitochondria of Mus spretus sperm are not destroyed in the cytoplasm of Mus musculus oocytes in the interspecies mouse crosses [31]. Based on our observation, we predicted the involvement in the destruction of paternal mitochondria of the protein scavenger ubiquitin [77], an $8.5 \mathrm{kDa}$ protein that prompts metaphase-anaphase transition by destroying the cyclin component of MPF during meiosis and mitosis (reviewed by Pines [57]). We recently confirmed this hypothesis by observing conjugation of ubiquitin to the sperm mitochondrial sheath in bovine one-, two- and four-cell embryos [79]. It appears that certain proteins of sperm mitochondria are tagged with ubiquitin during spermatogenesis and immediately recognized by intrinsic ubiquitin of oocyte cytoplasm, which mediates the targeting of sperm mitochondria towards lysosomes and/or proteasomes. The association of oocyte-derived lysosomes and multivesiculated bodies with the sperm mitochondrial sheath, previously shown by transmission electron microscopy $[26,82,83]$ can be visualized by labeling live oocytes fertilized with MitoTracker-tagged sperm by a vital lysosomal probe LysoTracker [79]. These observations may explain how the suppression of the paternal mitochondrial genome is achieved during mammalian development. Species-specificity of sperm mitochondrion elimination [31] may be explained by differences in the amino acid sequence of the individual constituents of ubiquitin conjugation machinery and by the inability of the oocyte cytoplasm to recognize the proteins of the outer mitochondrial membrane from a foreign species.
Other sperm tail accessory structures, including fibrous sheath, outer dense fibers and microtubule doublets are eliminated by oocyte cytoplasm at various stages of embryonic development. Although the FS disappears within a few hours after the sperm is incorporated into bovine oocyte [77], the ODF and axonemal microtubules degenerate slowly and are still seen at the two-cell stage [26, 68, 76, 77].

\section{EFFECT OF PATERNALLY CONTRIBUTED ZYGOTIC COMPONENTS ON THE OUTCOME OF ASSISTED FERTILIZATION}

Mammalian and human oocytes can be successfully fertilized and brought to term by the intracytoplasmic injection of a mature spermatozoon (ICSI; $[29,52,100]$ ), or by the injection or fusion of an immature spermatogenic cell such as primary $[47,62]$ or secondary [33] spermatocyte, or a round spermatid [45, 46]. Consequently, injections of mature spermatozoa and elongated or round spermatids are now used to treat human infertility $[19,52,94]$. Normal development was achieved using the injection or fusion of spermatogenic cells with the oocytes in the mouse [33, 46, 62], hamster [45] and rabbit [71]. In addition to germ cells, nuclear transfer of somatic cells isolated from fetal, juvenile or even adult tissues resulted in the production of live offspring $[8,9,101,102]$. Predicted by the articles on the reprogramming of thymocyte nuclei in oocyte cytoplasm [13, 88-90], the idea of cloning from somatic cells, or at least of using it for nuclear transfer has been around for more than a decade. However, the overall success rate of methods such as transfer of nuclei of somatic cells remains very low. Since the injection of isolated somatic cell nuclei gave similarly low success rates [102], one possible reason is the collision of organelles and molecules from the donor cell with those of the recipient ooplasm after fusion. For instance, it is not 
known whether the foreign, i.e. somatic (or immature germ cell) mitochondria, brought into oocyte cytoplasm by nuclear transfer or intracytoplasmic injection, are eliminated by the oocyte in a manner identical to that of natural fertilization. The persistence of two different mitochondrial genomes in the cytoplasm of a single cell, a condition referred to as heteroplasmy, may interfere with the development of such embryos and result in severe anomalies. Similarly, sperm accessory structures introduced into an oocyte by ICSI or round spermatid injection (ROSI) may collide with normal zygotic development. It was shown previously that the acrosome and subacrosomal layer of perinuclear theca often persist on the surface of rhesus sperm injected into mature rhesus oocytes, and cause a heterogeneous decondensation of sperm chromatin and abnormal pronuclear development $[24,76]$. The persistence of subacrosomal PT was recently shown in human ICSI zygotes [65] and may explain the higher rate of chromosomal abnormalities seen in human fetuses conceived by ICSI $[20,28]$, which may be mainly due to chromosome anomaly of the patient, as compared to those from conventional in vitro fertilization. In contrast to a mature human and primate spermatozoon carrying a single, proximal centriole destined to organize the sperm aster after fertilization $[24,69$, $76]$, the round spermatid contains an additional, distal centriole, which appears to be involved in the formation of sperm axoneme [80]. It is not clear whether either of these centrioles is competent to organize the sperm aster after ROSI, and whether the additional centriole present in the ROSI-conceived zygote does not interfere with pronuclear development and formation of the first mitotic spindle. More research is necessary to address these important questions related to assisted fertilization.

\section{CONCLUSION}

The ultrastructural studies of Szöllösi and others demonstrated that the fate of various sperm accessory structures after fertilization is precisely determined by their interactions with the oocyte. In the past few years, the use of molecular tools for fertilization studies culminated in a string of new discoveries, including that of the biparentally contributed centrosome in the zygotes of non-rodent mammals and the elimination of sperm mitochondria by an ubiquitindependent proteolytic pathway during preimplantation development. Perinuclear theca, once thought to play a marginal, if any role in fertilization, now appears to contribute the oocyte activating factor, which assures the initiation of the embryonic cell cycle and the activation of anti-polyspermy defense. The reduction of oocyte centrosomes and the ability of oocyte cytoplasm to remodel the nucleus of a somatic cell, previously described by Szöllösi and his colleagues, appear to assure the developmental success of embryos procreated by assisted fertilization methods such as ICSI, ROSI and nuclear transfer. It is necessary to emphasize, however, that the remodeling of gametes after assisted fertilization may not necessarily mirror that seen during natural fertilization. Focused research into molecular and cellular mechanisms of assisted fertilization, using relevant animal models, is necessary to substantiate their clinical use.

\section{ACKNOWLEDGEMENTS}

We are pleased to acknowledge our colleagues and collaborators for stimulating discussions and for sharing their unpublished data: Dr A. Chan, Dr T. Dominko, Dr L. Hewitson, Dr M. Luetjens, Dr G. Manandhar, Dr R. Moreno, Dr R. Oko, Dr J. Ramalho-Santos, Dr C. Simerly and Dr Y. Terada. The technical and clerical assistance of Ms M. Emme, Ms C. Martinovich, Ms D. Takahashi, Mr M. Webb, and staff members of the Oregon Regional Primate Research Center, Beaverton, OR, is sincerely appreciated. Special thanks belong to Dr J.E. Fléchon for inspiring this review and to $\mathrm{DrC}$. Thibault for reading the manuscript. Original research reviewed in parts of this paper was supported by grants from NIH and USDA to G.S. 


\section{REFERENCES}

[1] Allen J.F., Separate sexes and the mitochondrial theory of ageing, J. Theor. Biol. 180 (1996) 135-140.

[2] Almeida E.A.C., Huovila A.-P.J., Sutherland A.E, Stephens L.E., Calarco P.G., Shaw L.M., Mercurio A.M., Sonnenberg A., Primakoff P., Myles D.G., White J.M., Mouse egg integrin $\alpha 6 \beta 1$ functions as a sperm receptor, Cell 81 (1995) 1095-1104.

[3] Ankel-Simons F., Cummins J.M., Misconceptions about mitochondria and mammalian fertilization: implications for theories on human evolution, Proc. Natl. Acad. Sci. USA 93 (1996) 13859-13863.

[4] Battaglia D.E., Koehler J.K., Klein N.A., Tucker M.J., Failure of oocyte activation after intracytoplasmic sperm injection using roundheaded sperm, Fertil. Steril. 68 (1997) 118-122.

[5] Boveri T., Zellen-studien: Ueber die Natur der Centrosomen, IV Fisher, Jena, Germany, 1901.

[6] Breed W., Simerly C., Navara C.S., Vanderberg J., Schatten G., Distribution of microtubules in eggs and early embryos of the marsupial, Monodelphis domestica, Dev. Biol. 164 (1994) 230 240.

[7] Bronson R.A., Fusi F.M., Integrins and human reproduction, Mol. Hum. Rep. 2 (1996) 153-168.

[8] Campbell K.H., Loi P., Cappai P., Wilmut J., Improved development to blastocyst of ovine nuclear transfer embryos reconstructed during the presumptive $S$-phase of enucleated activated oocytes, Biol. Reprod. 50 (1994) 1385-1393.

[9] Campbell K., McWhir J., Ritchie W., Wilmut J., Sheep cloned by nuclear transfer from a cultured cell line, Nature 380 (1996) 64-66.

[10] Courtens J.L., Courot M., Fléchon J.E., The perinuclear substance of boar, bull, ram and rabbit spermatozoa, J. Ultrastruct, Res. 57 (1976) 54-64

[11] Crozet N., Behavior of sperm centriole during sheep fertilization, Eur. J. Cell Biol. 53 (1990) 326-332.

[12] Cummins J.M., Wakayma T., Yanagimachi R., Fate of microinjected sperm components in the mouse oocyte and embryo, Zygote 5 (1997) $301-308$.

[13] Czolowska R., Modlinski J.A., Tarkowski A.K., Behaviour of thymocyte nuclei in non-activated and activated mouse oocytes, J. Cell Sci. 69 (1984) 19-34

[14] Ecklund P.S., Levine L., Mouse sperm basic nuclear protein. Electrophoretic characterization and fate after fertilization, J. Cell Biol. 66 (1975) 251-262.

[15] Evans J.P., Schultz R.M., Kopf G.S., Mouse sperm-egg plasma membrane interactions: anal$y$ sis of roles of egg integrins and the mouse sperm homologue of $\mathrm{PH}-30$ (fertilin) $\beta$, J. Cell Sci. 108 (1995) 3267-3278.
[16] Fawcett D.W., The mammalian spermatozoon, Dev. Biol. 44 (1975) 394-436.

[17] Fechter J., Schöneberg A., Schatten G., The excision and disassembly of sperm tail microtubules during sea urchin fertilization: requirements for microtubule dynamics, Cell Motil. Cytoskel. 35 (1996) 281-288.

[18] Felix M., Antony C., Write M., Maro B., Centrosome assembly in vitro: role of $\gamma$-tubulin recruitment in Xenopus sperm aster formation, J. Cell Biol. 124 (1994) 19-31.

[19] Fishel S., Green S., Bishop M., Pregnancy after intracytoplasmic injection of spermatid, Lancet 345 (1995) 1641-1642.

[20] Flaherty S.P., Payne D., Swann N., Mathews D., Aetiology of failed and abnormal fertilization after intracytoplasmic sperm injection, Hum. Reprod. 10 (1995) 2623-2629.

[21] Gould R.R., Borisy G.G., The pericentriolar material in Chinese hamster ovary cells nucleates microtubule formation, J. Cell Biol. 73 (1977) 601-615.

[22] Gresson R.A.R., Presence of the sperm middlepiece in the fertilized egg of the mouse (Mus musculus), Nature 145 (1940) 425.

[23] Herrada G., Wolgemuth D.J., The mouse transcription factor Stat 4 is expressed in haploid male germ cells and is present in the perinuclear theca of spermatozoa, J. Cell Sci. 110 (1997) 1543-1553.

[24] Hewitson L.C., Simerly C.R., Tengowski M.W., Sutovsky P., Navara C.S., Haavisto A.J., Schatten G., Microtubule and DNA configurations during Rhesus intracytoplasmic sperm injection: successes and failures, Biol. Reprod. 55 (1996) 271-280.

[25] Hewitson L.C., Haavisto A., Simerly C., Jones J., Schatten G., Microtubule organisation and chromatin configurations in hamster oocytes during fertilization and parthenogenetic activation, and after insemination with human sperm, Biol. Reprod. 57 ( 1997 ) 967-975.

[26] Hiraoka J., Hirao Y., Fate of sperm tail components after incorporation into the hamster egg, Gamete Res. 19 (1988) 369-380.

[27] Hutchinson C.A., Newbold J.E., Potter S.S., Edgel M.M., Maternal inheritance of mammalian mitochondrial DNA, Nature 251 (1974) 536-538.

[28] 1n't Veld P., Brandenburg H., Verhoeff A., Dhont. M., Los F., Sex chromosomal abnormalities and intracytoplasmic sperm injection, Lancet 773 (1995) 346

[29] Iritani A., Micromanipulation of gametes for in vitro assisted fertilization, Mol. Reprod. Dev. 28 (1991) 199-207.

[30] Joshi H.C., $\gamma$-tubulin: the hub of cellular microtubule assemblies, BioEssays 15 (1993) 637-643.

[31] Kaneda H., Hayashi J.-I., Takahama S., Taya C., Fischer-Lindahl K., Yonekawa H., Elimination of paternal mitochondrial DNA in intraspecific crosses during early mouse embryogenesis, Proc. Natl. Acad. Sci. USA 92 (1995) 4542-4546. 
[32] Kim N.-H., Simerly C., Funahashi H., Schatten G., Day B.N., Microtubule organization in porcine oocytes during fertilization and parthenogenesis, Biol. Reprod. 54 (1996) 1397-1404.

[33] Kimura Y., Yanagimachi R., Development of normal mice from oocytes injected with secondary spermatocyte nuclei, Biol. Reprod. 53 (1995) 855-862.

[34] Kimura Y., Yanagimachi R., Intracytoplasmic sperm injection in the mouse, Biol. Reprod. 52 (1995) 709-720.

[35] Kimura Y., Yanagimachi R., Kuretake S., Bortkiewicz H., Perry A.C.F., Yanagimachi H., Analysis of mouse oocyte activation suggests the involvement of sperm perinuclear material, Biol. Reprod. 58 (1998) 1407-1415.

[36] Kopečný V., Pavlok A., Autoradiographic study of mouse spermatozoan arginine-rich nuclear protein in fertilization, J. Exp. Zool. 191 (1975) 85-96.

[37] Le Guen P., Crozet N., Microtubule and centrosome distribution during sheep fertilization, Eur. J. Cell Biol. 48 (1989) 239-249.

[38] Long C.R., Duncan R.P., Robl J.M., Isolation and characterization of MPM-2-reactive sperm proteins: homology to components of the outer dense fibers and segmented columns, Biol. Reprod. 57 (1997) 246-254.

[39] Longo F.J., Incorporation and dispersal of sperm surface antigens in plasma membranes of inseminated sea urchin (Arbacia punctulata) eggs and oocytes, Dev. Biol. 131 (1989) 37-43.

[40] Macaulay C., Forbes D.J., Assembly of the nuclear pore: biochemically distinct steps revealed with NEM, GTPYS, and BAPTA, J. Cell Biol. 132 (1996) 5-20.

[41] Manandhar G., Sutovsky P., Joshi H.C., Steams T., Schatten G., Centrosome reduction during mouse spermiogenesis, Dev. Biol. 203 (1998) 424-434.

[42] Meier E., Miller B.R., Forbes D.J., Nuclear pore complex assembly studied with a biochemical assay for annulate lamellae formation, J. Cell Biol. 129 (1995) 1459-1472.

[43] Navara C.S., First N.L., Schatten G., Microtubule organisation in the cow during fertilization, polyspermy, parthenogenesis, and nuclear transfer: the role of the sperm aster, Dev. Biol. 162 (1994) 29-40.

[44] Newport J.W., Nuclear reconstitution in vitro: stages of assembly around protein-free DNA, Cell 48 (1987) 205-217.

[45] Ogura A., Yanagimachi R., Round spermatid nuclei injected into hamster oocytes form pronuclei and participate in syngamy, Biol. Reprod. 48 (1993) 219-225

[46] Ogura A., Matsuda J., Yanagimachi R., Birth of normal young after electrofusion of mouse oocytes with round spermatids, Proc. Nati. Acad. Sci. USA 91 (1994) 7460-7462.
[47] Ogura A., Wakayama T., Suzuki O., Shin T.-Y., Matsuda J., Kobayashi Y., Chromosomes of mouse primary spermatocytes undergo meiotic division after incorporation into homologous immature oocytes, Zygote 5 (1997) 177-182.

[48] Oko R., Clermont Y., Isolation, structure and protein composition of the perforatorium of rat spermatozoa, Biol. Reprod. 39 (1988) 673-687.

[49] Oko R., Maravei D., Protein composition of the perinuclear theca of bull spermatozoa, Biol. Reprod. 50 (1994) 1000-1014.

[50] Oko R., Maravei D., Distribution and possible role of perinuclear theca proteins during bovine spermiogenesis, Microsc. Res. Tech. 32 (1995) 520-532.

[51] Panté N., Aebi U., Sequential binding of import ligands to distinct nuclear pore regjons during their nuclear import, Science 273 (1996) 17291732.

152] Palermo G., Joris H., Devroey P., Van Steirteghem A.C., Pregnancies after intracytoplasmic sperm injection of single spermatozoon into an oocyte, Lancet 340 (1992) 17-18.

[53] Parrington J., Swann K., Schevchenko V.I., Sesay A.K., Lai F.A., Calcium oscillations in mammalian eggs triggered by a soluble sperm factor, Nature 379 (1996) 364-368.

[54] Perreault S.D., Wolf R.A., Zirkin B.R., The role of disulfide bond reduction during mammalian sperm nuclear decondensation in vivo, Dev. Biol. 101 ( 1984) 160-167.

[55] Pfaller R., Smythe C., Newport J.W., Assembly/disassembly of the nuclear envelope membrane: cell cycle-dependent binding of nuclear membrane vesicles to chromatin in vitro, Cell 65 (1991) 209-217.

[56] Phillips D.M., Spermiogenesis, Academic Press, New York, 1974.

[57] Pines J., Ubiquitin with everything, Nature 371 (1994) 742-743.

[58] Pinto-Correia C., Collas P., Ponce de Leon A., Robl J.M., Chromatin and microtubule organisation in the first cell cycle in rabbit parthenotes and nuclear transplant embryos, Mol. Reprod. Dev. 34 (1993) 33-42.

[59] Pinto-Correia C., Poccia D.L., Chang T. Robl J.M., Dephosphorylation of sperm midpiece antigens initiates aster formation in rabbit oocytes, Proc. Natl. Acad. Sci. USA 91 (1994) 7894-7898.

[60] Poccia D., Collas P., Transforming sperm nuclei into male pronuclei in vivo and in vitro, in: Pedersen R.A., Schatten G.P. (Eds.), Current Topics in Developmental Biology, vol. 34, Academic Press Inc., New York, 1996, pp. 25-88.

[61] Sanders M.A., Salisbury J.L., Centrin-mediated microtubule severing during flageller excision in Chlamydomonas reinhardtii, J. Cell Biol. 108 (1989) 1751-1760. 
[62] Sasagawa I., Kuretake S., Eppig J.J., Yanagimachi R., Mouse primary spermatocytes complete two meiotic divisions within the oocyte cytoplasm, Biol. Reprod. 58 (1998) 248-254.

[63] Sathananthan A.H., Kola I., Osborne J., Trounson A., Ng S.C., Bongso A., Ratnam S.S., Centrioles at the beginning of human development, Proc. Natl. Acad. Sci. USA 88 (1991) 48064810.

[64] Sathananthan A.H., Ratnam S.S., Ng S.C., Tarín J.J., Gianaroli L., Trounson A., The sperm centriole: its inheritance, replication and perpetuation in early human embryos, Hum. Reprod. 1 (1996) 345-356.

[65] Sathananthan A.H., Szell A., Ng S.C., Kausche A., Lacham-Kaplan O., Trounson A., Is the acrosome reaction a prerequisite for sperm incorporation after intra-cytoplasmic sperm injection?, Reprod. Fert. Dev. 9 (1997) 703-709.

[66] Schatten G., Simerly C., Schatten H., Microtubule configurations during fertilization, mitosis, and early development in the mouse and the requirement for egg microtubule-mediated motility during mammalian fertilization, Proc. Natl. Acad. Sci. USA 82 (1985) 4152-4156.

[67] Schatten H., Schatten G., Mazia D., Balczon R., Simerly $\mathrm{C}$., Behavior of centrosomes during fertilization and cell division in mouse oocytes and sea urchin eggs, Proc. Natl. Acad. Sci. USA 83 (1986) 105-109.

[68] Shalgi R., Magnus A., Jones R., Phillips D.M., Fate of sperm organelles during early embryogenesis in the rat, Mol. Reprod. Dev. 37 (1994) 264-271

[69] Simerly C., Wu G., Zoran S., Ord T., Rawlins R., Jones J., Navara C., Gerrity M., Rinehart J., Binor Z., Asch R., Schatten G., The paternal inheritance of the centrosome, the cell's microtubule-organizing center, in humans and the implications for infertility, Nature Med. 1 (1995) 47-53.

[70] Snell W.J., White J.M., The molecules of mammalian fertilization, Cell 85 (1996) 629-637.

[7]] Sofikitis N.V., Toda T., Miyagawa I., Zavos P.M., Pasyianos P., Mastelou E., Beneficial effects of electrical stimulation before round spermatid nuclei injections into rabbit oocytes on fertilization and subsequent embryonic development, Fertil. Steril. 65 (1996) 176-185.

[72] Soupart P., Strong P.A., Ultrastructural observations on polyspermic penetration of zona pellucida-free human oocytes inseminated in vitro, Fertil. Steril. 26 (1975) 523-537.

[73] Stearns T., Evans L., Kirschner M., $\gamma$-tubulin is a highly conserved component of the centrosome, Cell 65 (1991) 825-836.

[74] Stefanini M., Oura C., Zamboni L., Ultrastructure of fertilization in the mouse. 2. Penetration of the sperm into the ovum, J. Submicr. Cytol, 1 (1969) 1-23.
[75] Sutorsky P., Schatten G., Depletion of glutathione during oocyte maturation reversibly blocks the decondensation of the male pronucleus and pronuclear apposition during fertilization, Biol. Reprod. 56 (1997) 1503-1512.

176] Sutovsky P., Hewitson L., Simerly C.R., Tengowski M.W., Navara C.S., Haavisto A., Schatten $\mathrm{G}$., Intracytoplasmic sperm injection (ICSI) for Rhesus monkey fertilization results in unusual chromatin, cytoskeletal, and membrane events, but eventually leads to pronuclear development and sperm aster assembly, Hum. Reprod. 11 (1996) 1703-1712.

[77] Sutovsky P., Navara C.S., Schatten G., The fate of the sperm mitochondria, and the incorporation, conversion and disassembly of the, sperm tail structures during bovine fertilization in vitro, Biol. Reprod. 55 (1996) I!95-1205.

1781 Sutovsky P., Oko R., Hewitson L., Schatten G., The removal of the sperm perinuclear theca and its association with the bovine oocyte surface during fertilization, Dev. Biol. 188 (1997) 75-84

[79] Sutovsky P., Moreno R., Schatten G., Sperm mitochondrial ubiquitination and a model explaining the strictly maternal mtDNA inheritance in mammals, Mol. Biol. Cell Suppl. 9 (1998) 309a.

[80] Sutovsky P., Ramalho-Santos J., Moreno R., Oko R., Hewitson L., Schatten G., On-stage identification and selection of single round spermatids using a vital, mitochondrion-specific fluorescent probe MitoTracker ${ }^{\mathrm{TM}}$, Hum. Reprod. (1999) (in press)

181] Sutovsky P., Simerly C., Hewitson L., Schatten G., Assembly of nuclear pore complexes and annulate lamellae promotes normal pronuclear development in fertilized mammalian oocytes, J. Cell Sci. 111 (1998) 2841-2854.

[82] Szöllösi D., The fate of the sperm middle-piece mitochondria in the rat egg, J. Exp. Zool. 159 (1965) 367-378.

[83] Szöllösi D., Oocyte maturation and paternal contribution to the embryo in mammals, Curr. Top. Pathol. 64 (1976) 9-27.

[84] Szöllösi D., Hunter R.H.F., Ultrastructural aspects of fertilization in the domestic pig: sperm penetration and pronucleus formation, J. Anat. 116 (1973) 181-206.

[85] Szöllösi D., Ozil J.P., De novo formation of centrioles in parthenogenetically activated, diploidized rabbit embryos, Biol. Cell 72 (1991) 61-66.

[86] Szöllösi M.S., Szöllösi D., 'Blebbing' of the nuclear envelope of mouse zygotes, early embryos and hybrid cells, J. Cell Sci. 91 (1988) 257-267.

[87] Szöllösi D., Calarco P., Donahue R.P., Absence of centrioles in the first and second meiotic spindles of mouse oocytes, J. Cell Sci. 11 (1972) 521-541. 
[88] Szöllösi D., Czolowska R., Soltynska M.S., Tarkowski A.K., Ultrastructure of cell fusion and premature chromosome condensation (PCC) of thymocyte nuclei in metaphase II mouse oocytes, Biol. Cell 56 (1986) 239-250.

[89] Szöllösi D., Czolowska R., Szöllösi M.S, Tarkowski A.K., Remodeling of thymocyte nuclei in activated mouse oocytes: an ultrastructural study, Eur. J. Cell Biol. 42 (1986) 140-151.

[90] Szöllösi D., Czolowska R., Szöllösi M.S., Tarkowski A.K., Remodeling of thymocyte nuclei depends on the time of their transfer into activated, homologous oocytes, J. Cell Sci. 91 (1988) 603-613.

[91] Szöllösi D., Szöllösi M.S., Czolowska R., Tarkowski A.K., Sperm penetration into immature mouse oocytes and nuclear changes during maturation: an EM study, Biol. Cell 69 (1990) 53-64.

[92] Szöllösi M.S., Adenot P., Szöllösi D., Centrosomes with striated rootlets in rabbit zygotes, Zygote 4 (1996) 173-179.

[93] Szöllösi D., Czolowska R., Borsuk E., Szöllösi M.S., Debey P., Nuclear envelope removal/ maintenance determines the structural and functional remodelling of embryonic red blood cell nuclei in activated mouse oocytes, Zygote 6 (1998) 65-73.

[94] Tesarik J., Mendoza C., Testart J., Viable embryos from injection of round spermatids into oocytes, N. Engl. J. Med. 333 (1995) 525.

[95] Thompson R.S., Moore Smith D., Zamboni L., Fertilization of mouse ova in vitro: an electron microscopic study, Fertil. Steril. 25 (1974) 222249.

[96] Usui N., Morphological differences in nuclear materials released from hamster sperm heads at an early stage of incorporation into immature oocytes, mature oocytes, or fertilized eggs, Mol. Reprod. Dev. 44 (1996) 132-140.

[97] Usui N., Yanagimachi R., Behavior of hamster sperm nuclei incorporated into eggs at various stages of maturation, fertilization and early development, J. Ultrastruct. Res. 57 (1976) 276288.

[98] Usui N., Ogura A., Kimura Y., Yanagimachi R., Sperm nuclear envelope: breakdown of intrinsic envelope and de novo formation in hamster oocytes or eggs, Zygote 5 (1997) 35-46.

[99] Van Blerkom J., Bell H., Henry G., The occurrence, recognition and developmental fate of pseudo-multipronuclear eggs after in vitro fertilization of human oocytes, Hum. Reprod. 2 (1987) 217-225.

[100] Van Steirteghem A., Nagy S., Joris H., Liu J., Staessen C., Smitz J., Wisanto A., Devroey P., High fertilization and implantation rates after intracytoplasmic sperm injections, Hum. Reprod. 8 (1993) 1061-1066.

[101] Vignon X., Chesné P., Le Bourhis D., Fléchon J.E., Heyman Y., Renard J.P., Developmental potential of embryos reconstructed from enucleated matured oocytes fused with cultured somatic cells, C. R. Acad. Sci. Paris 321 (1998) 735745.

[102] Wakayama T., Perry A.C.F., Zucotti M., Johnson K.R., Yanagimachi R., Full-term development of mice from enucleated oocytes injected with cumulus cell nuclei, Nature 394 (1998) 369-374.

[103] Woolley D.M., Fawcett D.W., The degeneration and disappearance of the centrioles during the development of the rat spermatozoon, Anat. Rec. 177 (1973) 289-302.

[104] Wu G., Simerly C., Zoran S.S., Funte L.R., Rawlins R., Binor Z., Schatten G., Microtubule and chromatin configurations during fertilization and early development in rhesus monkeys, and regulation by intracellular calcium ions, Biol. Reprod. 55 (1996) 260-270.

[105] Xu Y.S., Overton W.R., Marman J.L., Leonard J.C., McCoy S.P., Buttler G.H., Li H., Complete replication of human sperm genome in egg extracts from Xenopus laevis, Biol. Reprod. 58 (1998) 661-667. 